\title{
OCCUPATIONAL EXPOSURES AND MALE INFERTILITY, A CASE-CONTROL STUDY
}

\author{
By \\ El-Helaly $\mathrm{ME}^{1}$, Awadalla $\mathrm{NJ}^{1}$, Mansour $\mathrm{M}^{2}$, \\ El-Biomy $\mathrm{Y}^{2}$ and El Samanoudy AZ ${ }^{3}$ \\ ${ }^{1}$ Public Health and Preventive Medicine Department, \\ ${ }^{2}$ Dermatology and Andrology Department, \\ ${ }^{3}$ Biochemistry Department, Faculty of Medicine, \\ Mansoura University, Mansoura, Egypt.
}

\begin{abstract}
:
Objectives: this study was carried out to examine the association between male infertility and certain occupational exposures. Methods: a case-control study was carried out from 2008 to 2009; on 255 infertile men and 267 fertile men controls. Occupational exposure to certain chemical, physical and psychological work-place hazards were assessed by self-report questionnaire. General and andrology medical examination were done for all participants, however semen analysis was done only for the infertile men cases, because the fertile men controls refused to give semen samples. Results: after adjustment of confounders, the results revealed that the following occupational exposure factors significantly increased the risk of male infertility: solvents and painting materials(OR: 3.88, 95\% CI: 1.50-10.03), lead (OR: 5.43, 95\% CI: 1.28-23.13), VDTs and computers (OR: 8.01, 95\% CI: 4.03-15.87), shift work (OR: 3.60, 95\% CI: 1.12-11.57) and workrelated stress (Fairly present: OR 3.11, 95\% CI: 1.85-5.24; Often present: OR: 3.76, 95\% CI: 1.96-7.52) Conclusion: although the limitations of this study, it supports other studies that ring the bell to minimize the exposure to the work-place hazards that may affect the fertility of men workers.
\end{abstract}

Keywords: -Occupational -Exposure -Male -Infertility -Semen. 


\section{Introduction:}

In comparison to women's health, health researchers pay little attention to men's health. Recently, male reproductive function in the general population has attracted increasing attention due to reports suggesting that the occurrence of several biological problems affecting the male genital tract have increased during the last 50 years (Telisman et al., 2000; De Fleurian et al., 2009). An obvious undesirable consequence of reproductive toxicants is infertility. Infertility, defined as the inability to conceive after 12 months of unprotected intercourse, affects 10-15 percent of all couples (Mosher and Pratt, 1991). In roughly half of cases, a male factor is identified, while an occult male factor may be involved in 15-24 percent of cases in which no etiology is dicovered ("unexplained" infertility) (Skakkebaek et al.,1994).

Semen quality analysis, the standard clinical approach to assess male reproductive capacity, can be considered a sensitive biological marker of exposure to toxicants at the work place (Bigelow et al., 1998). Based on semen quality analysis, it has been stressed that the percentage of men whose sperm count has fallen below the level associated with optimal fertility, has increased (Carlsen et al., 1992; Jouannet and Auger, 1996). This may be related to the consequence of environmental or occupational exposure to chemicals, radiation, toxicants and heat (Friedler, 1996).

However, the knowledge existing today regarding the influence of chemical, physical and emotional factors on male fertility is limited. Moreover, in recent decades, the industrial world has become inundated with an ever-increasing number of chemical and physical agents about whose toxicity in general, and toxicity on the male reproductive system, very little is known (Oliva et al., 2001; Sheiner et al., 2003; Kumar, 2004). So, the objective of this study was to explore the association between male infertility and certain occupational exposures.

\section{Subjects and Methods:}

\section{Study population}

A case-control study was carried out from 2008 to 2009. Cases were males having their first visit for infertility evaluation at the Andrology clinic of the Mansoura University Hospital, Mansoura, Egypt. Only 601 men accepted to participate in the study giving a formal consent. Of the total of 601 men, 255 were included in the study after fulfilling the following criteria: 
1- No female factors of infertility (such as: pelvic inflammatory diseases, tubal occlusion, endometriosis, or endocrine and ovulation defects).

2- Absence of medical and surgical causes of infertility such as diabetes mellitus (DM), febrile illnesses, urinary tract infection, sexually transmitted diseases, a history of chemotherapy or radiotherapy, varicoceles, undescended testes, small testes or testicular injury. Those diseases were diagnosed by medical past history, andrology examination by andrology specialists, fasting blood glucose, urine analysis, other investigations and Doppler examination of both testes. Also, cases with family history of any genetic disease were excluded.

3- Having complete data including questionnaires and semen analysis.

The mean age of the cases was: 30.10 \pm 6.20 years and all of them had primary infertility. Controls were recruited from husbands accompanying their pregnant women who were attending obstetric clinic of the Mansoura University Hospital, for antenatal care of their pregnancies. Of the total of 273 husbands who accepted to participate in the study giving a formal consent, only 267 had no past history of infertility and they composed the control group. The mean age of the controls was $29.92 \pm 6.11$ years

\section{Methods:}

\section{Assessment of occupational and environmental exposure:}

All participants completed extensive self-report questionnaire on socioeconomic, medical, occupational and environmental factors. The questionnaire included questions about the presence and duration of occupational exposures occurred within the past month, including exposures to pesticides; solvents (including: glues, adhesives, polishes, thinner or turpentine); painting materials; gasoline; welding or soldering fumes; mineral oils or wax; printing materials; anesthetic gases; lead; VDTs; radiation; excess heat; whole body vibration. Also, the questionnaire included questions about the presence of workrelated stress (no stress, fairly present, often present) and shift work.

\section{Semen analysis:}

All cases agreed to give semen samples, however all the controls refused to give semen sample, as they considered themselves as fertile men with no need for semen analysis. All cases asked to collect their semen at the Andrology clinic lab by masturbation into a sterile plastic 
specimen cup. Subjects were instructed to abstain from ejaculation for at least 3 days prior to sampling. All semen samples were processed and analyzed by computer aided semen analyzer (CASA, version 10 HTM-IVOS; Hamilton Thorne Research, Beverly, Mass). Each semen sample was liquefied for at least 20 minutes, but no longer than 1 hour prior to semen analysis. Volume, $\mathrm{pH}$, sperm concentration per $\mathrm{ml}$, sperm motility, sperm morphology (Morphological Index) and sperm viability were examined according to the WHO guidelines for the examination of human semen (WHO, 1999).

To measure both sperm concentration and motility, $5 \mathrm{ml}$ of semen from each sample was placed into a pre-warmed $\left(37^{\circ} \mathrm{C}\right)$ Makler counting chamber. A minimum of 200 sperm cells from at least four different fields were analyzed from each specimen. Motile sperm were defined according to the World Health Organization (WHO) grade as 'a' grade sperm (rapidly progressive with a velocity $\geq 25 \mathrm{~mm} / \mathrm{s}$ at $37^{\circ} \mathrm{C}$ ) and 'b' grade sperm (slow/sluggish progressive with a velocity $\geq 5 \mathrm{~mm} / \mathrm{s}$ but, $<25 \mathrm{~mm} / \mathrm{s}$ ). Progressive motile sperm were defined as grade 'a' sperm (WHO, 1999).

Concerning sperm morphology, at least two slides were made for each fresh semen sample. The resulting thin smear was allowed to air dry for 1 hour before staining with the Diff-Quik staining kit (Dade Behring AG, Dudingen, Switzerland). Morphological assessment was performed with a Nikon microscope using an oil immersion 1006 objective (Nikon Company, Tokyo, Japan). A minimum of 200 sperm cells was counted from the 2 slides for each specimen. Strict scoring criteria were used to classify men as having normal or subnormal morphology, according to Kruger et al. (1988).

\section{Statistical analysis:}

Baseline demographic information for cases and controls was compared. Next, bivariate analyses were performed to determine the association between fertility status and exposure factors. Bivariate analyses were performed using student- $t$ test for continuous variables and the Pearson Chi-Squared and Fisher's exact tests for categorical and dichotomous variables. Next, a multivariable logistic regression model was employed using forward Wald strategy. Candidate variables had a bivariate association with fertility of $\mathrm{p} \leq$ 0.05 . Odds ratio (OR) and $95 \%$ confidence intervals (CI) were calculated for casecontrol associations with factors suspected to affect male fertility with adjustment of the confounders. Statistical analysis was performed using SPSS, version 16.0, on a personal computer. A two-tailed $\mathrm{p}$ value 
less than 0.05 was considered statistically significant and $\mathrm{p}$ value less than 0.01 was considered high statistical significance.

\section{Results:}

There was statistically non-significant difference between cases and controls regarding age, residence, education levels and economic levels. However, cases differed significantly from the controls concerning smoking and body mass index (BMI) (Table 1).

Concerning semen quality of the cases, the means of the morphological index and sperm motility were lower than WHO (1999) standards for normal individuals. However, the means of $\mathrm{pH}$, semen volume, sperm density, WBCs and RBCs were within normal, according to WHO (1999) (Table 2).
Infertile men were significantly more likely to be exposed to solvents and painting materials (OR: 3.88, 95\% CI: 1.50-10.03); lead (OR: 5.43, 95\% CI: 1.28-23.13) and VDTs (OR: 8.01, 95\% CI: 4.03-15.87) than were infertile men. Also, shift work (OR: 3.60, 95\% CI: 1.12-11.57) and work-related stress (Fairly present: OR 3.11, 95\% CI: 1.85-5.24; Often present: OR: $3.76,95 \%$ CI: 1.96-7.52) were significantly associated with infertility. Moreover, smoking and BMI were considered significant risk factors of male infertility. On the other hand, no significant associations were found between infertility and exposure to pesticides, gasoline, welding fumes, anesthetic gases, printing materials, excess heat, whole-body vibration, and radiation (Table 3). 
Table 1: Characteristics of the study population.

\begin{tabular}{|c|c|c|c|c|c|c|}
\hline Characteristic & \multicolumn{2}{|c|}{$\begin{array}{c}\text { Cases } \\
(\mathrm{n}=255)\end{array}$} & \multicolumn{2}{|c|}{$\begin{array}{l}\text { Controls } \\
(\mathrm{n}=267)\end{array}$} & Test & $\mathbf{P}$ \\
\hline & \multicolumn{2}{|c|}{ Mean \pm SD } & \multicolumn{2}{|c|}{ Mean \pm SD } & & \\
\hline Age (years): & 30.10 & 6.20 & 29.93 & 6.11 & $\mathrm{t}^{\mathrm{a}}=0.33$ & $>0.05$ \\
\hline BMI $\left(\mathrm{Kg} / \mathrm{m}^{2}\right)$ : & 27.80 & 4.85 & 26.80 & 4.13 & $t=2.15$ & $<0.01$ \\
\hline & $\mathbf{n}$ & $\%$ & $\mathbf{n}$ & $\%$ & & \\
\hline $\begin{array}{l}\text { Smoking: } \\
\text {-Non-smoker. } \\
\text {-Current smoker. }\end{array}$ & $\begin{array}{c}97 \\
158\end{array}$ & $\begin{array}{l}38.00 \\
62.00\end{array}$ & $\begin{array}{c}171 \\
96\end{array}$ & $\begin{array}{l}69.01 \\
36.00\end{array}$ & $\chi^{2 b}=35.09$ & $<0.01$ \\
\hline $\begin{array}{l}\text { Residence: } \\
\text {-Rural. } \\
\text {-urban. }\end{array}$ & $\begin{array}{c}64 \\
191\end{array}$ & $\begin{array}{l}25.09 \\
74.90\end{array}$ & $\begin{array}{c}62 \\
205\end{array}$ & $\begin{array}{l}23.22 \\
76.77\end{array}$ & $\chi^{2}=0.25$ & $>0.05$ \\
\hline $\begin{array}{l}\text { Education: } \\
\text {-Illiterate. } \\
\text {-Read and write/ Primary school. } \\
\text {-Preparatory/ Secondary school. } \\
\text {-University graduated or higher. }\end{array}$ & $\begin{array}{c}26 \\
29 \\
107 \\
93\end{array}$ & $\begin{array}{l}10.19 \\
11.37 \\
41.96 \\
36.47\end{array}$ & $\begin{array}{c}18 \\
34 \\
125 \\
90\end{array}$ & $\begin{array}{r}6.74 \\
12.73 \\
46.81 \\
33.71\end{array}$ & $\chi^{2}=3.02$ & $>0.05$ \\
\hline $\begin{array}{l}\text { Income: } \\
\text {-Not enough. } \\
\text {-Enough. } \\
\text {-Enough with saving. }\end{array}$ & $\begin{array}{c}156 \\
107 \\
4\end{array}$ & $\begin{array}{c}58.41 \\
40.12 \\
1.50\end{array}$ & $\begin{array}{c}127 \\
121 \\
7\end{array}$ & $\begin{array}{c}49.80 \\
47.51 \\
2.72\end{array}$ & $\chi^{2}=4.38$ & $>0.05$ \\
\hline
\end{tabular}

\footnotetext{
a student-t test

b Pearson Chi-Square test.
} 
Table 2: Semen quality of the cases.

\begin{tabular}{|c|c|c|}
\hline Semen quality parameters & $\begin{array}{c}\text { Mean } \pm \text { SD } \\
\text { Median ( minimum-maximum) }\end{array}$ & $\begin{array}{l}\text { WHO (1999) } \\
\text { accepted levels }\end{array}$ \\
\hline -Abstinence (day) & $\begin{array}{c}4.09 \pm 1.00 \\
4(3-9)\end{array}$ & 3 \\
\hline$-\mathrm{P}^{\mathrm{H}}$ & $\begin{array}{c}7.231 \pm 0.08 \\
7.33(7.21-8.00)\end{array}$ & $7.2-8.0$ \\
\hline -WBCs (cell) & $\begin{array}{c}2.29 \pm 1.37 \\
2.00(1.00-5.00)\end{array}$ & $<5 \mathrm{HPF}^{\mathrm{a}}$ \\
\hline -RBCs (cell) & $\begin{array}{c}2.11 \pm 1.35 \\
2.12(0.00-4.00)\end{array}$ & $<5 \mathrm{HPF}$ \\
\hline -Semen Volume (ml) & $\begin{array}{c}3.55 \pm 1.27 \\
3.50(0.70-7.00)\end{array}$ & $\geq 2.00 \mathrm{~mL}$ \\
\hline -Sperm Density $\left(10^{6} / \mathrm{mL}\right)$ & $\begin{array}{c}39.97 \pm 39.13 \\
23.90(0.80-218.70)\end{array}$ & $\geq 20.00$ \\
\hline -Morphological Index & $\begin{array}{c}14.95 \pm 8.51 \\
14.01(0.12-49.00)\end{array}$ & $\begin{array}{c}>15.00 \% \\
\text { normal sperms }\end{array}$ \\
\hline -Sperm Motility (\%) & $\begin{array}{c}45.81 \pm 26.82 \\
40.02(1.00-90.00)\end{array}$ & $\geq 50.00 \%$ \\
\hline
\end{tabular}

${ }^{\text {a }} \mathrm{HPF}=$ high power field 
Table 3: Odds Ratios (OR) of factors associated with male infertility:

\begin{tabular}{|c|c|c|c|c|c|c|}
\hline Factors $^{\mathrm{a}}$ & \multicolumn{2}{|c|}{$\begin{array}{c}\text { Cases } \\
(\mathrm{n}=255) \\
\mathbf{n} / \% \\
\end{array}$} & \multicolumn{2}{|c|}{$\begin{array}{c}\text { Controls } \\
\begin{array}{c}(n=267) \\
n / \%\end{array} \\
\end{array}$} & $\begin{array}{c}\mathbf{O R}^{\mathbf{b}} \\
(95 \% \mathrm{CI})\end{array}$ & $\mathbf{P}$ \\
\hline \multicolumn{7}{|l|}{ Occupational exposures: } \\
\hline -Solvents and painting materials & 31 & 12.2 & 9 & 3.4 & $\begin{array}{c}3.88 \\
(1.50-10.03)\end{array}$ & $<0.05$ \\
\hline -Gasoline & 19 & 7.5 & 10 & 3.7 & $\begin{array}{c}1.03 \\
(0.30-3.50)\end{array}$ & $>0.05$ \\
\hline -Lead & 18 & 7.1 & 3 & 1.1 & $\begin{array}{c}5.43 \\
(1.28-23.13)\end{array}$ & $<0.05$ \\
\hline -Welding fumes & 23 & 9.0 & 3 & 1.1 & $\begin{array}{c}3.95 \\
(0.58-26.97)\end{array}$ & $>0.05$ \\
\hline -VDTs and computers & 81 & 31.8 & 14 & 5.2 & $\begin{array}{c}8.01 \\
(4.03-15.87)\end{array}$ & $<0.01$ \\
\hline -Excess heat & 25 & 9.8 & 13 & 4.9 & $\begin{array}{c}1.47 \\
(0.59-3.61)\end{array}$ & $>0.05$ \\
\hline -Stress & & & & & & \\
\hline -Fairly present & 118 & 46.3 & 46 & 17.2 & $\begin{array}{c}3.11 \\
(1.85-5.24)\end{array}$ & $<0.01$ \\
\hline -Often present & 57 & 22.4 & 27 & 10.1 & $\begin{array}{c}3.76 \\
(1.96-7.52)\end{array}$ & $<0.01$ \\
\hline -Shift work & 21 & 8.2 & 7 & 2.6 & $\begin{array}{c}3.60 \\
(1.12-11.57)\end{array}$ & $<0.05$ \\
\hline Smoking & 158 & 62.0 & 96 & 36.0 & $\begin{array}{c}2.622 \\
(1.66-4.14)\end{array}$ & $<0.01$ \\
\hline BMI $\left(\mathbf{K g} / \mathbf{m}^{2}\right):$ mean $\pm \mathrm{SD}$ & \multicolumn{2}{|c|}{$\begin{array}{c}27.80 \pm \\
4.85\end{array}$} & \multicolumn{2}{|c|}{$\begin{array}{c}26.80 \pm \\
4.13\end{array}$} & $\begin{array}{c}1.07 \\
(1.06-1.13\end{array}$ & $<0.01$ \\
\hline
\end{tabular}

${ }^{a}$ Exposure categories were not mutually exclusive.

b There was non-statistically significant difference between cases and the controls concerning the following exposure factors which had not been entered in the logestic model: pesticides, vibration, anesthetic gases, printing materials and radiation. 


\section{DISCCUSION:}

The present case-control study aimed to explore the association between infertility and occupational exposures through analysis exposure factors. Moreover, the present study evaluated the different types of occupational exposures based on a self-report detailed questionnaire. Doubtless, questionnaire as a tool of qualitative measurement of exposure has disadvantages such as recall bias and exposure misclassification; and is inferior to the biological assessment of exposure which is more precise. Despite these limitations, questionnaires have provided good estimates of exposures (Gracia et al., 2005; De Fleurian et al., 2009 ). In this study the biological assessment could not be used because of the cost and the diversity of chemicals that the subjects were exposed to. So, in the present study' questionnaire, the answer "yes" for the studied exposures was limited to the intense and frequent work-place exposures.

Concerning adjustment of confounders, there was non-significant difference between cases and controls regarding other confounders such as age, residence, education levels or economic levels. However, as expected, infertility was significantly associated with smoking (Vine et al., 1994) (OR: 2.622,95\% CI: 1.66-4.14) and body mass index, (OR: 1.07, 95\% CI: 1.06-1.13) even after adjustment by logistic regression.

According to the studied occupational chemical exposures, the present study found that infertile men were significantly more likely to be exposed to solvents and painting materials; and lead. However, no significant associations were found between infertility and exposure to pesticides, gasoline, welding fumes, anesthetic gases and printing materials.

Organic solvents are widely used in various industrial settings, such as electronics, shoemaking, furniture manufacturing, painting, dry cleaning, metal industries, reinforced plastic industries, and the production of paints, glues, and other chemicals (Hooiveld et al., 2006). In animal experiments, 2-bromopropane, ethylene glycol ethers, n-hexane, and thinners, particularly the components ethyl acetate and xylene, can cause testicular damage and degeneration (Yamada, 1993 and Ichihara et al., 1996).

Many epidemiological studies were carried out to investigate the association between occupational exposure to solvents and the risk of male infertility. Our results support those of other studies which found that occupational exposure to solvents 
significantly increased the risk of male infertility ( Cherry et al., 2001; Kurinczuk and Clarke, 2001; De Fleurian et al., 2009). On the contrary, other studies have been negative (Spinelli et al., 1997 and Kolstad et al., 1999). In summary, Tielemans et al. (1999) stated that, it seems that there is a clear association between solvent exposure and impaired semen parameters.

Our results concerning significantly increased risk of infertility in relation to occupational exposure to lead, confirm other several occupational surveys that linked exposure to inorganic lead with reduced sperm count and other signs of male reproductive toxicity (Lancranjan et al., 1975; Apostoli et al., 2000; Shiau et al., 2004; De Fleurian et al., 2009). However our study found non-significant risk of infertility for exposure to welding fumes. This was in agreement with De Fleurian et al 2009 and against Garcia et al., 2005.

Surprisingly, the present study found no significant association between infertility and exposure to pesticide. This was in agreement with Gracia et al. (2005) and Clementia et al. (2008), but they reported that their studies had several limitations. On the other hand, Roeleveld and Bretveld (2008) reported that several studies from the 1970s and 1980s showed that occupational exposure to specific pesticides such as dibromochloropropane, ethylene dibromide, and chlordecone had detrimental effects on semen quality, affecting sperm count, sperm motility and morphology. However, the majority of studies published since 2000 reported some effects of pesticide exposure on semen quality or time-to-pregnancy, but the results were not consistent (Roeleveld and Bretveld, 2008) .

Concerning the studied occupational physical exposures, the results of our study revealed that infertile men were significantly more likely to work with VDTs and computers (OR: 8.01, 95\% CI: 4.0315.87) than were fertile men. However, no significant associations were found between infertility and exposure to excess heat, whole-body vibration or radiation.

Many jobs that require heavy daily computer use have been found to be stressful (Carajon, 1993; Mocci et al., 2001) and stress is a risk factor of infertility (Sheiner et al., 2003). Also, prolonged sitting in front of VDT may affect semen quality through increasing temperature of the testes (De Fleurian et al., 2009). Moreover, the computer-released radiation causes changes in enzymatic antioxidant defense system and, leads to oxidant stress (Ergüder and Durak, 2006). Other studies reported that electromagnetic field 
exposure from electronic equipment and VDT may decrease melatonin level, leading to oxidative stress (Tan et al., 2000) which may lead to impairment of semen quality. On the other hand, other studies found no significant association between exposure to VDTs and male infertility (Gracia et al., 2005; De Fleurian et al., 2009).

Many studies reported increased risk of infertility among workers exposed to high temperature (Thonneau et al., 1996; Thonneau et al., 1998; De Fleurian et al., 2009); however, the present study did not find a significant increased risk of infertility in relation to exposure to excess heat which is in accordance with Oliva et al. (2001). This may be due to low exposure times or intensities among the studied population whose did not include workers in industries associated with high temperature exposure as iron and steel industry or glass industry.

The present study found that shift work (OR: 3.60, 95\% CI: 1.12-11.57) significantly increased the risk of male infertility. This is in accordance with Irgens et al.(1999) who reported a tendency toward reduced semen quality among shift workers (OR, 1.46; CI, 0.89 to 2.40) which may be explained by stress and specific lifestyle factors. Also, Tuntiseranee et al. (1998) estimated the effect of long working hours and shift work on time to pregnancy. They found that long working hours is a risk factor for subfecundity, however, shiftwork was not associated with subfecundity in their study. However, Zhu et al. (2003), examined whether shift work is associated with reduced fecundity as estimated by time to pregnancy (TTP). They found no evidence of a causal association between shift work and subfecundity.

In our study, work-related stress significantly increased the risk of male infertility with a dose-response effect (OR 3.11, 95\% CI: $1.85-5.24$ for fairly stress and OR: $3.76,95 \%$ CI: 1.96-7.52 for often stress). These results support other studies (Sheriner et al., 2003) that found significant increased risk of infertility in relation to work-related stress. Psychological stress has been demonstrated to depress testosterone levels in humans and rodents (McGrady, 1984) and has a negative impact on semen quality (Stoleru et al., 1993; Gracia et al., 2005). In addition, stress may affect libido and sexual performance that could indirectly affect fertility (Chia and Tay, 2001).

The present study had several limitations: no biological monitoring done, occupational exposures were assessed by a questionnaire not by actual exposure monitoring; and the fertile male controls refused to give semen samples for semen 
analysis. However, the sample size of the present study was considerably large and participation rate was good. Based on the results of this study we will arrange for another studies focusing on special work categories which is considered at more risk for male infertility as painters, with more sophisticated biological monitoring and exposure assessment.

\section{Conclusion:}

This case-control study found that work-place exposure to solvents and painting materials, lead, VDTs and computers, shift work and work-related stress significantly increased the risk of male infertility. Although the limitations of this study, it supports other studies that ring the bell to minimize the exposure to the work-place hazards that may affect the fertility of men workers.

\section{References:}

1. Apostoli, P., Bellini, A., Porru, S. and Bisanti, L. (2000). The effect of lead on male fertility: a time to pregnancy (TTP) study. Am J Ind Med, 38:310-5.

2. Bigelow PL., Jarrell J, Young MR, Keefe TJ and Love EJ (1998). Association of semen quality and occupational factors: comparison of case- control analysis and analysis of continuous variables. Fertil Steril, 69, 11-18.

3. Carajon P (1993). Job design and job stress in office workers. Egonomics, 5: 463-77.

4. Carlsen E, Giwercman A, Keiding N and Skakkebaek N (1992). Evidence for decreasing quality of semen during the past 50 years. Br Med J, 305: 609-613.
5. Cherry N, Labreche F, Collins $\mathrm{J}$ and Tulandi $\mathrm{T}$ (2001). Occupational exposure to solvents and male infertility. Occup Environ Med, 58, 635-40.

6. Chia SE and Tay SK (2001). Occupational risk for male infertility: A Case-Control Study of 218 Infertile and 227 Fertile Men. J Occup Environ Med, 43: 946-51

7. Clementia M, Tibonib GM, Causinc R, Roccad C, et al. (2008). Pesticides and fertility: An epidemiological study in Northeast Italy and review of the literature. Reproductive Toxicology, 26: 113-18.

8. De Fleurian G, Perrin J and Ecochard R (2009). Occupational exposures obtained by questionnaire in clinical practice and their association with semen quality. J Androl; 30:566.

9. Ergüder IB and Durak I (2006). Effects of computer use on human salivary oxidant/antioxidant status. Journal of Biological Sciences; 6:14-17.

10. Friedler G (1996). Paternal exposures: impact on reproductive and developmental outcome: an overview. Pharmacol Biochem Behav, 55: 691-700.

11. Gracia CR, Mary D, Coutifaris SC, Guzick DS, et al. (2005). Occupational exposures and male infertility. Am J Epidemiol, 162:729-733.

12. Hooiveld M, Haveman W, Roskes K, Bretveld $\mathrm{R}$, et al. (2006). Adverse reproductive outcomes among male painters with occupational exposure to organic solvents. Occup Environ Med; 63:538-544.

13. Ichihara G, Asaeda N, Kumazawa T, Tagawa $Y$, et al. (1996). Testicular toxicity of 2-bromopropane. J Occup Health, 38: 205-206

14. Irgens A, Krüger K and Ulstein M (1999). The Effect of Male Occupational Exposure in Infertile Couples in Norway. J Occup Env Med, 41: 1116-20.

15. Jouannet P and Auger J (1996). Declining sperm counts? More research is needed. Andrologia, 28: 302-303. 
16. Kolstad HA, Bisanti L and Roeleveld N (1999). Time to pregnancy for men occupationally exposed to styrene in several European reinforced plastics companies. Scand J Work Environ Health, 25:66-9.

17. Kruger TF, Acosta AA, Simmons KF, Swanson RJ, et al. (1988). Predictive value of abnormal sperm morphology in in-vitro fertilization. Fertil Steril, 49:112-117.

18. Kumar S (2004).Occupational Exposure Associated with Reproductive Dysfunction. J Occup Health, 46: 1-19

19. Kurinczuk JJ and Clarke M (2001). Case-control study of leatherwork and male infertility. Occup Environ Med, 58: 217-24.

20. Lancranjan I, Popescu HI, Gavanescu O, et al. (1975). Reproductive ability of workmen occupationally exposed to lead. Arch Environ Health, 30:396-401.

21. McGrady AV (1984). Effects of psychological stress on male reproduction: a review. Arch Androl, 13: 1-7.

22. Mocci F, Serra A and Corrias GA (2001). Psychological factors and visual fatigue in working with video display terminals. Occup Environ Med, 58: 267-71.

23. Mosher WD and Pratt WF (1991). Fecundity and infertility in the United States: incidence and trends. (Editorial). Fertil Steril, 56:192-3.

24. Oliva A, Spira A and Multigner L (2001). Contribution of environmental factors to the risk of male infertility .Human Reproduction, 16: 1768-76

25. Roeleveld N and Bretveld R (2008). The impact of pesticides on male fertility. Curr Opin Obstet Gynecol, 20:229-33.

26. Sheiner EK, Sheiner E, Hammel RD, Potashnik G, et al. (2003). Effect of Occupational Exposures on Male Fertility: Literature Review. Industrial Health, 41: 55-62

27. Shiau CY, Wang JD and Chen PC (2004). Decreased fecundity among male lead workers. Occup Environ Med, 61:915-923.
28. Skakkebaek NE, Giwercman A and De Kretser D (1994). Pathogenesis and management of male infertility. Lancet, 343:1473-8.

29. Spinelli A, Figa TI and Osborn J (1997). Time to pregnancy and occupation in a group of Italian women. Int J Epidemiol, 26:601-9.

30. Stoleru S, Teglas JP, Fermanian J and Spira A (1993). Psychological factors in the aetiology of infertility: a prospective cohort study. Hum Reprod, 8: 1039-1046.

31. Tan DX, Manchester LC, Reiter RJ, Qi WB, et al. (2000). Significance of melatonin in antioxidant defense system: Reactions and products. Biol Signals Recept, 9:137-159

32. Telisman S, Cvitkovic ' P, Jurasovic' J and Pizent A(2000). Semen Quality and Reproductive Endocrine Function in Relation to Biomarkers of Lead, Cadmium, Zinc, and Copper in Men. Environmental Health Perspectives, 108:45-53

33. Thonneau P, Ducot B, Bugan L, Mieusset R, et al. (1996) Heat exposure as a hazard to male fertility- letter. Lancet 347: 204-5.

34. Thonneau P, Bujan L, Multigner L and Mieusset R (1998). Occupational heat exposure and male fertility: a review. Hum. Reprod, 13:2122-25.

35. Tielemans E, Burdorf A and Velde ER (1999). Occupational related exposures and reduced semen quality: a case-control study. Fertility and Sterility, 4:690-696.

36. Tuntiseranee P, Olsen J, Geater A and Kor-anantakul O (1998). Are long working hours and shiftwork risk factors for subfecundity? A study among couples from southern Thailand. Occup Environ Med, 55:99-105

37. Vine MF, Margolin BH, Morrison HI and Hulka BS (1994). Cigarette smoking and sperm density: a meta-analysis. Fertil Steril, 61: 35-43.

38. World Health Organization (1999). WHO Laboratory Manual for the Examination of Human Semen and Semen-Cervical Mucus Interaction. New York: Cambridge University Press. 
39. Yamada K (1993). Influence of lacquer thinner and some organic solvents on reproductive and accessory reproductive organs in the male rat. Biol Pharm Bull, 16:425-7.
40. Zhu JL, Hjollund NH, Boggild $\mathrm{H}$ and Olsen J (2003). Shift work and subfecundity: a causal link or an artefact? Occup Environ Med, 60:e12. 